\title{
TO THE HISTORY OF FINANCIAL AND ECONOMIC ACTIVITY OF THE VOLGA RIVER TRANSPORT DURING THE NEP AND THE FIRST FIVE-YEAR PLAN PERIOD
}

\author{
Olesya Aleksandrovna Gomanenko \\ Candidate of Sciences (History), Associate Professor, \\ Department of Social Work and Pedagogy, \\ Volgograd State University \\ gomanenko.olesya@mail.ru, srm@volsu.ru \\ Prosp. Universitetsky, 100, 400062 Volgograd, Russian Federation

\section{Vladimir Viktorovich Bulatov} \\ Doctor of Sciences (History), \\ Deputy Chief of the Research Work Department, \\ Centre for the Recent History Documentation of the Volgograd Region. \\ vbulatov@rambler.ru \\ Dymchenko St., 16, 400005 Volgograd, Russian Federation
}

\begin{abstract}
The Volga transport for 10 years (1923-1934) was influenced by all those changes which happened in the national economy of the country during the periods of the New Economic Policy and its transition to the forced industrialization. Since 1923 attempts of its delivery to concession in connection with the project of creation of the Volga-Don-Azov Sea hydraulic engineering constructions by means of the Western firms and banks took place. In 1929 those attempts ended without any results. Most likely, threat of outflow from the USSR of scarce currency in the form of profits of concessionaires was the main cause. That threat moved promises of foreign firms to significantly modernize and expand the Volga transport with all its coastal infrastructure, and also to promote creation of "new freights" in a zone of operations of the Volga fleet.

Up to its reorganization in 1934 the Volga fleet constantly experienced the financial and technical difficulties caused by wear of watercrafts, low tariffs for a cargo transportation, etc. However, these low tariffs allowed the large new enterprises and constructions of the first five-year plans period to reduce their transport expenses. It favorably affected the process of industrialization of the Volga region and other ones. Losses on freight transportation were offset by the Volga water transport due to passenger traffic by increasing the high efficiency of passenger capacity of ships, an intensification of a passenger traffic and increase of a passenger tariff.

Key words: Volga water transport, New Economic Policy, concession, industrialization, productivity,

\section{К ИСТОРИИ ФИНАНСОВО-ХОЗЯЙСТВЕННОЙ ДЕЯТЕЛЬНОСТИ ВОЛЖСКОГО РЕЧНОГО ТРАНСПОРТА В ПЕРИОД НЭПА И ПЕРВОЙ ПЯТИЛЕТКИ}

\section{Олеся Александровна Гоманенко}

Кандидат исторических наук, доцент кафедры социальной работы и педагогики, Волгоградский государственный университет gomanenko.olesya@mail.ru,srm@volsu.ru просп. Университетский, 100, 400062 г. Волгоград, Российская Федерация 


\section{Владимир Викторович Булатов}

Доктор исторических наук, заместитель начальника отдела научно-исследовательской работы, Государственное казенное учреждение Волгоградской области «Центр документации новейшей истории Волгоградской области» vbulatov@rambler.ru ул. Дымченко, 16, 400005 г. Волгоград, Российская Федерация

Аннотация. В статье анализируется деятельность волжского водного транспорта в периоды нэпа и перехода к форсированной индустриализации. Показаны попытки сдачи его в концессию, предпринятые в 1923-1928 годах. Выявлены причины его финансовых и технических трудностей в годы индустриализации. Показан удельный вес речного флота Волги в воднотранспортном обслуживании страны. Вскрыты источники компенсации убытков.

Ключевые слова: волжский водный транспорт, нэп, концессия, индустриализация, производительность, рентабельность, грузопассажирские перевозки.

После Октября 1917 г. мероприятия новой власти по устранению элементов товарного хозяйства и традиционных имущественных отношений только усугубили и без того общее тяжелое положение экономики России. В основе народнохозяйственного регресса лежало непроизводительное потребление национального дохода в годы военного лихолетья и революций, дезорганизация транспорта, «топливный» и «металлический голод» и пр. В начале 1920-х гг. все народное хозяйство страны сползло к состоянию экономической катастрофы.

Как и другие отрасли, в полуразрушенном состоянии пребывал отечественный водный транспорт. В 1920 г. число судов составляло менее 50 \% по сравнению с 1913 г., причем большинство из них требовало существенного ремонта. Рынок грузопассажирских речных и морских перевозок сжался до минимума [7, c. 189]. Не избежал такой участи и Волжский речной флот. За годы гражданской войны его техническое состояние резко ухудшилось, восстановление проходило медленно.

Состоявшийся в марте 1921 г. Х съезд Российской коммунистической партии (большевиков) провозгласил переход к новой экономической политике (далее- нэп). Народное хозяйство страны постепенно восстанавливалось. В сфере водного транспорта стал проявляться интерес к прежним дореволюционным проектам. При этом имели место модернизация и доработка их до уровня новых требований.

К середине 1920-х гг. существовавшее тогда единое Волжское государственное речное пароходство оказалось связанным с по- пыткой реализовать крупнейший инфраструктурный проект - создать Волго-Доно-Азовскую водную магистраль. Ее главнейшими звеньями должны были стать Волго-Донской судоходный канал и комплекс Волго-Доно-Азовских и Волго-Каспийских гидротехнических сооружений [1].

Размах проекта был грандиозным, однако внутренних ресурсов для его реализации тогда не хватало. Выход из создавшегося положения стал усматриваться в широком привлечении иностранных инвесторов посредством концессий, что стало возможным благодаря изданию 23 ноября 1920 г. Советом народных комиссаров РСФСР (далее - СНК) декрета «Об общих юридических и экономических условиях концессий». Осенью 1925 г. Главный концессионный комитет при СНК СССР (Главконцесском) дал соответствующую директиву концессионным комиссиям при торговых представительствах Советского Союза в Париже, Берлине, Лондоне и Риме. Директивой ставилась задача заинтересовать и привлечь к реализации советского проекта финансово и технически состоятельных иностранных инвесторов [5, л. 3]. Однако весь 1926 г. никаких предложений от иностранцев не поступало.

Лишь к середине следующего года иностранные фирмы стали проявлять интерес к сооружению Волго-Доно-Азовского пути. В июне 1927 г. к полпреду СССР во Франции Х.Г. Раковскому обратился бывший директор широко известного в царской России волжского грузопассажирского АО «Кавказ и Меркурий» Ю.И. Гессен [4, л. 11]. 
Тот представлял интересы германских фирм «Бриске и Проль» и «Юлиус Бергер», входивших в состав мощного строительного консорциума «Юлиус Бергер». По уверениям Гессена, эти фирмы были готовы принять на себя обязательства по финансированию и строительству Волго-Донского канала и гидротехнических сооружений на Дону, а также по реконструкции Ростовского порта. Реализовать проект предполагалось посредством сдачи иностранцам кредитно-подрядной концессии, предполагавшей, что финансировать и строить объекты будут германские фирмы, а эксплуатировать их будет советская сторона. Реальность осуществления проекта гарантировалась как техническим опытом германского консорциума, так и его финансовой поддержкой со стороны группы германо-голландо-американских банков [1, с. 106-110].

Однако неизбежно вставал вопрос о будущем источнике возврата иностранцам не только инвестированных ими в сооружение магистрали капиталов, но и уплату процентов по ним. А затраты обещали быть огромными. Так, еще в 1918 г. было подсчитано, что объем работ только по одному Волго-Донскому каналу должен был составить как минимум половину объема работ, произведенных при строительстве Панамского канала.

Германская сторона в лице Ю.И. Гессена предложила свой вариант такого источника. Речь пошла, и уже не в первый раз, о сдаче в СССР еще одной концессии - концессии на эксплуатацию Волжского государственного речного пароходства. Его предполагалось акционировать и создать смешанное советско-германское акционерное общество «Волжско-Камский Ллойд» (далее - «Вокаллойд»). По замыслу, советский участник «Вокаллойда» должен был отчислять германскому участнику свою долю прибыли от операций смешанного $\mathrm{AO}$ с целью постепенного возмещения инвестированных в создание всего комплекса волго-донских сооружений иностранных средств, как и выплату по ним процентов [1, с. 157-158].

Германская сторона была заинтересована в скорейшем возмещении капиталов и выплате процентов. Это, по ее мнению, могло быть достигнуто через увеличение грузооборота пароходства. Немцы планировали осуще- ствить реконструкцию и рост тоннажа речного флота на Волге и Каме, создать флот для будущего Волго-Донского канала и реконструировать береговую инфраструктуру Волжского речного пароходства. Была выдвинута также идея создания «новых грузов» для Волго-Донского водного пути, путем содействия развитию промыслов, промышленности и торговли в зоне операций «Вокаллойда» [1, с. 157].

Полпред Раковский известил о предложении Гессена Торговое представительство СССР в Париже. Торгпредство информировало председателя Главконцесскома В.Н. Ксандрова, а тот, в свою очередь, доложил о сути происходящего непосредственно главе СНК СССР А.И. Рыкову. Ксандров напомнил председателю правительства, что предложение Гессена о создании «Вокаллойда» уже рассматривалось на заседаниях Политбюро ЦК РКП (б) в 1923-1924 гг. [6, с. 319].

То есть проект «Вокаллойда» был не новым. Еще 16 июля 1923 г. Политбюро одобрило предложение Гессена, но при условии, что преобладающую роль в смешанном $\mathrm{AO}$ будет играть советское правительство. Условия были согласованы. Однако 14 августа 1924 г. Политбюро решило отклонить проект. Главным мотивом этого решения было несогласие с передачей акционерному обществу всего тоннажа речного пароходства на Волге и Каме, как и всей береговой инфраструктуры. К моменту второго заседания Политбюро пароходство хотя и находилось в тяжелом положении, но уже наметились перспективы его технического и финансового оздоровления [4, л. 8-9].

Вопрос об акционировании Волжского речного пароходства, как и связанный с ним вопрос сооружения и обустройства Волго-Донского пути, завис. Ксандров снова обратился к Рыкову по поводу «указаний в направлении этого дела» [4, л. 22]. Вскоре «направление» стало принимать совершенно иной вектор движения. Главконцесском через концессионную комиссию при Торгпредстве СССР в Берлине выдвинул Гессену свое предложение. Если ранее план Гессена предусматривал концессию на Волжское речное пароходство, то теперь Главконцесском выдвигал идею создания вместе с иностранцами не связанного с Волжским пароходством тоннажа. То есть 
речь зашла о создании нового «смешанного» пароходства, которое должно было функционировать на Волге и Каме одновременно с государственным пароходством [4, л. 24-26].

В определенной мере этот вариант отражал проводившуюся в тот период концессионную политику, направленную на поощрение создания иностранцами на территории СССР новых предприятий, а не на реконструкцию и расширение уже существовавших.

Ю.И. Гессен в ответ на предложение Главконцесскома выдвинул вполне обоснованные возражения. Он заметил, что если на Волге и Каме будет создаваться новое пароходство, то для него иностранной стороной будут приобретены новейшие пароходы и теплоходы зарубежной постройки, да и береговые сооружения будут оснащены по последнему слову техники. По сравнению с судами Волжского речного пароходства, у судов нового пароходства снизится потребление топлива, и их эксплуатация станет более экономичной. В итоге появление такого конкурента поставит государственное пароходство в невыгодные условия. Гессен вновь стал настаивать на том, чтобы привлечь иностранный капитал для реорганизации существующего Волжского речного пароходства. По всей видимости, эти доводы показались Главконцесскому вполне убедительными, поскольку в обращении В.Н. Ксандрова в Политбюро летом 1928 г. фигурировал лишь проект смешанного АО «Вокаллойд» по варианту Гессена [4, л. 26-27].

В декабре 1928 г. Главконцесском обратился в концессионную комиссию Народного комиссариата путей сообщения СССР (далее - НКПС) с просьбой предоставить сведения о состоянии Волжского пароходства. Они были необходимы для выводов о целесообразности сдачи его в концессию.
Ответ последовал в феврале 1929 г., причем он предварялся запиской наркома путей сообщения А.Э. Рудзутака.

Нарком рассматривал Волжское пароходство как рентабельное предприятие, несмотря на имевшиеся недостатки. Он прогнозировал дальнейший рост рентабельности при условии выделения государственных дотаций. То есть Рудзутак был против концессии. Данные НКПС в целом подтверждали его оптимизм, правда, не во всем. Основная масса единиц флота имела возраст от 21 до 35 лет и приближалась к предельным срокам службы. Вставал вопрос о необходимости постройки новых судов, что диктовалось не только износом плавсредств, но и возраставшим грузооборотом, прирост которого прогнозировался в объеме около $11 \%$ ежегодно [3, л. 62-63, 65, 67-68 об.].

Строительство нового флота и береговых сооружений для Волжского речного пароходства в период 1929-1933 гг. требовало капитальных вложений на сумму более 210 млн рублей. Из собственных источников пароходство на эти цели могло выделить лишь 79,8 млн. Остальные 130,2 млн рублей ожидались в виде государственной дотации. Но здесь возникали сомнения. Например, в 1925 и 1926 гг. дополнительные ассигнования пароходству вообще не выделялись, в 1927 г. дотации составили всего 2 млн рублей, а в 1928 г. - 3,8 млн [3, л. 68 об.].

Тем не менее, несмотря на износ плавсредств, производительность флота все же росла (табл. 1).

Производительность флота имела резерв дальнейшего роста в случае ликвидации простоя судов, особенно в части сухогрузов. Однако отмечался и рост годового расхода на 1 индивидуальную силу по паротепловому фло-

Таблича 1

Динамика производительности флота Волжского речного пароходск в 1925-1928 гг., \%
\begin{tabular}{|l|r|r|r|c|}
\hline \multicolumn{4}{|c|}{ Состав флота } & \multicolumn{4}{|c|}{ Годы } \\
\cline { 2 - 5 } & 1925 & 1926 & 1927 & 1928 (план) \\
\hline Буксиры & 100 & 97,0 & 110,3 & 116,0 \\
\hline Баржи сухогрузные & 100 & 108,5 & 137,0 & 141,8 \\
\hline Баржи нефтеналивные & 100 & 99,5 & 106,2 & 110,0 \\
\hline Всего & 100 & 101,6 & 117,8 & 122,6 \\
\hline
\end{tabular}

Примечание. Составлено и рассчитано по данным: [3, л. 70]. 
ту и на 1 тонну по непаровому флоту. Увеличение расходов произошло за счет роста цен на материалы для производства судоремонтных работ и роста заработной платы. Так, средняя заработная плата работника Волжского речного пароходства, с учетом начислений, составляла:

$$
\begin{aligned}
& \text { - в } 1925 \text { г. - } 66 \text { руб. } 17 \text { коп., } \\
& \text { - в } 1926 \text { г. - } 78 \text { руб., } \\
& \text { - в } 1927 \text { г. }-86 \text { руб. } 36 \text { коп. [3, л. } 70-70 \text { об.]. }
\end{aligned}
$$

Впрочем, соотношение доходов и расходов пароходства показывало положительное сальдо начиная с 1926 г. (табл. 2). Другими словами, оно приносило доходы.

Расчет доходности по итогам 1928 г. еще не был закончен и производился предварительно по самому осторожному сценарию. Вопервых, надо было учесть дополнительные расходы пароходства на организацию новой товаропассажирской линии. Во-вторых, доходы могли снизиться вследствие сокращения объемов транспортировки нефтепродуктов. Несмотря на это, руководство Волжского речного пароходства все же рассчитывало на увеличение показателя прибыли по сравнению с указанными в таблице предварительными данными на 1928 г. [3, л. 71].

Таким образом, наркомат также продемонстрировал отрицательное отношение к идее сдачи в концессию Волжского государственного речного пароходства. Здесь надо учитывать, что данное событие имело место в начале 1929 года. В советской практике именно с 1929 г. новые концессионные договоры в СССР уже не заключались, а шло либо перезаключение старых договоров, либо их ликвидация. Ю.И. Гессен тем временем не оставлял попыток провести проект «Вокаллойда», и весной летом 1929 г. он продолжал обращаться то к В.Н. Ксандрову, то к новому председателю Главконцесскома Л.Б. Каменеву.

Однако все было тщетно. В стране уже начался процесс свертывания концессионных отношений, обусловленный как экономическими, так и внеэкономическими причинами. Главная причина коренилась именно в экономической сфере. Весь комплекс существовавших проблем концессионной практики сформировал центральную проблему - вывоз иностранными концессионерами своих прибылей за рубеж. Проблема здесь заключалась в том, что они получали прибыль в советских червонцах, а затем обменивали их в Госбанке СССР на иностранную валюту и вывозили ее из страны.

Следовательно, росли государственные валютные расходы. Между тем валюта являлась одним из основных ресурсов для обеспечения успешного проведения начавшейся в стране форсированной индустриализации. В Советском Союзе стали наблюдаться изменения в формах привлечения иностранного капитала. Концессионные формы постепенно замещались неконцессионными формами, более совместимыми с реалиями советского экономического развития наступившей эпохи.

В 1929 г. волжский речной транспорт приобрел исключительное значение в общей системе транспортного обслуживания страны. Однако в условиях форсирования индустриализации его возможности уже не отвечали потребностям хозяйственных органов. СНК РСФСР отмечал, что заявленный Волжским речным пароходством объем грузооборота, который к концу Первой пятилетки (то есть к 1932 г.) должен был достигнуть 24 млн тонн, был превзойден заявками хозяйственников уже в 1930 году. Разрыв между возможностями и потребностями составил около 7 млн тонн.

\section{Соотношение доходов и расходов Волжского речного пароходства в 1925-1927 гг., тыс. руб.}

\begin{tabular}{|l|c|c|c|c|}
\hline \multirow{2}{*}{ Показатели } & \multicolumn{4}{|c|}{ Годы } \\
\cline { 2 - 5 } & 1925 & 1926 & 1927 & $\begin{array}{c}1928 \\
\text { (предварительно) }\end{array}$ \\
\hline Доходы & 42973 & 58866 & 59924 & 63367 \\
\hline Расходы & 43523 & 53176 & 50977 & 58983 \\
\hline Сальдо & -550 & +5690 & +8947 & +4384 \\
\hline
\end{tabular}

Примечание. Составлено по данным: [3, л. 70 об.]. 
В связи с этим правительство отмечало совершенно недостаточные темпы восстановления хозяйства волжского флота, особенно в части пополнения его новым тоннажем [2, л. 6].

В начале 1930-х гг. волжский флот уже выполнял 57,1 \% всех речных перевозок в Советском Союзе. В 1932 г. его доля достигла $60,2 \%$. Но размер инвестиций в реконструкцию и укрепление своих средств производства по-прежнему не соответствовал его удельному весу в перевозках. В 1933 г. по флоту Волги он составил только 22,2 \% от капиталовложений всех остальных речных пароходств СССР [8, л. 1 об.-2].

Фактом было и то, что волжский транспорт продолжал состоять из достаточно изношенного флота. 20 \% судов уже превзошли свой предельный возраст. По капиталовложениям и по величине тарифа Волжское управление речным транспортом (далее - ВУРТ) занимало одно из последних мест среди других управлений. Не имея достаточных капиталовложений, волжское хозяйство не могло произвести достаточных внутренних накоплений, хотя оно обслуживало основные промышленные и сельскохозяйственные районы.

Волжский флот продолжал работать по самым стабильно дешевым тарифам как среди других пароходств, так и по сравнению с железной дорогой (табл. 3).

По сравнению с железнодорожным сообщением тарифы на перевозки нефти волжским речным транспортом были в 5,5 раз ниже, хлеба - в 2,5 раза, соли - в 3,7 раза, леса в 2,3 раза. В сравнении с другими пароходствами Волжское перевозило многие грузы ниже себестоимости даже среди соседних пароходств, не говоря о северных и западных. Так, себестоимость нефтеперевозок МосковскоОкским флотом была в 2 раза выше Волжского, Северо-Западного - в 3,8 раза, Днепровского и Северного пароходств - в 4,6 раза. В перевозках хлеба, соли и леса в судах этими пароходствами стоимость была примерно в 2 раза выше, чем речным флотом Волги [8, л. 3 об. -4$]$.

Хотя волжский транспорт имел значительный удельный вес в бурно развивавшейся экономике периода первой и второй пятилеток, низкие тарифы снижали его рентабельность. Вероятно, низкие тарифы поддерживались директивными установками правительства. Бесспорно, они снижали эффективность перевозок для самого пароходства, но тем самым в общей системе обслуживаемых волжским флотом хозяйствующих субъектов транспортные издержки последних также снижались. В эпоху форсированной индустриализации это было важным моментом.

Но финансовое благополучие флота снижалось не только по причине низких тарифов и изношенности плавсредств. Были и причины организационного характера. Отрицательно, например, влияли систематические передачи судов в другие управления речным транспортом (далее - УРТы). Так, в течение двух навигаций 1932 и 1933 гг. имела место обратная передача Каспийскому морскому пароходству (Каспар) рейдового флота, который был принят ВУРТ 31 декабря 1931 года. Правда, тогда перераспределение судов не сильно отразилось на деятельности Волжского пароходства, так как рейдовый флот являлся вспомогательным к основной группе.

В соответствии с приказом Народного комиссариата водного транспорта (далее -

Таблииа 3

Стоимость перевозки одной тонны на 1000 км по основным пароходствам и железной дороге в 1932-1933 гг., коп.

\begin{tabular}{|c|r|r|r|r|}
\hline Пути перевозки & Нефть & Хлеб & \multicolumn{1}{|c|}{ Соль } & Лес в судах \\
\hline Пароходства: & & & & \\
\hline Волжское & 266 & 530 & 430 & 470 \\
\hline Московско-Окское & 535 & 900 & 720 & 720 \\
\hline Северо-Западное & 1000 & 910 & 910 & 810 \\
\hline Днепровское & 1230 & 810 & 1000 & 720 \\
\hline Северное & 1230 & 960 & 810 & 590 \\
\hline Железная дорога & 1443 & 1390 & 1601 & 1082 \\
\hline
\end{tabular}

Примечание. Составлено по данным: [8, л. 3 об.]. 
НКВТ) № 4 от 4 января 1933 г. в УРТах были организованы самостоятельные хозрасчетные предприятия - дирекции (нефтефлота, грузопассажирская, буксирно-сухогрузная, пути, строительства). В свою очередь это сильно усложнило структуру Волжского УРТа, удорожило и распылило аппарат. Поэтому вскоре на базе постановления СНК СССР и ЦК ВКП (б) «О работе железнодорожного транспорта» приказом начальника ВУРТа № 363 от 11 августа 1933 г. была ликвидирована дирекция нефтефлота, как и грузопассажирская и буксирно-сухогрузная дирекции. Их объединили в Отдел эксплуатации флота ВУРТ [8, л. 4 об., 5, 8]. Трудоемкий процесс организации таких дирекций, их комплектования не оправдал себя, так как эта форма управления оказалась неприемлемой для правильного маневрирования флотом.

В 1933 г. в соответствии с приказом НКВТ № 253 от 24 июня 1933 г. в ВУРТ от Всесоюзного объединения судостроительных и ремонтных заводов НКВТ (далее - Судостройремонт) были переданы заводы и мастерские: им. Ленина, им. Х годовщины Октябрьской революции, им. III Интернационала, им. К. Маркса, «Красный волгарь», «Память Парижской коммуны». Волжскому управлению речным транспортом по этому приказу было предложено организовать в Горьком хозрасчетную Судоремонтную дирекцию. Данная дирекция должна была осуществлять руководство и управление судоремонтными мастерским и затонами, как принятыми от Судостройремонта, так и всеми затонами Речных управлений речным транспортом (РУРТ), изъяв их из ведения последних. Вместо этого впоследствии был организован механико-судовой отдел из бывшего технического сектора [8, л. 4, 4 об., 8].

Прием от Судостройремонта астраханских заводов позволял сосредоточить и упорядочить капитальный ремонт и новое судостроение. Кроме того, эти меры были направлены на возложение большей ответственности на ВУРТ, на капитанов и механиков судов за текущий ремонт флота. ВУРТ считало целесообразным передачу в свое ведение всех верфей, заводов и мастерских бассейна из Управления судоремонтными предприятиями. Дело в том, что в тот период, когда были орга- низованы Всесоюзное объединение деревянного судостроения НКВТ (далее - ВОДС) и Судостройремонт, возросла договорная калькуляция работ, что мешало получению максимальной эффективности капиталовложений. Так, с появлением ВОДС отдельные типы деревянных судов новой постройки для волжского хозяйства подорожали более чем на $100 \%$.

В годы первых пятилеток с активным развитием промышленности возрастали капитальные вложения в хозяйство волжских районов. Так, в 1933 г. капитальные вложения Поволжья составили 1485,5 млн рублей, в том числе: Ивановская обл. - 289,2 млн рублей, Горьковский край - 415,6 млн рублей, Татарская республика - 78,0 млн рублей, Средневолжский край - 443,1 млн рублей, Нижневолжский край $-259,6$ млн рублей [8, л. 9 об.-10].

С навигации 1933 г. водный транспорт приступил к перевозкам продукции новых индустриальных единиц: Ярославского резинокомбината (шины, подошва, сажа); Горьковского автозавода им. Молотова; Кинешемского, Лопатинского и Козловского комбинатов стандартного домостроения; Шумерлинского деревообделочного комбината; Саратовского комбайн-завода; Сталинградского тракторного завода и др. Кроме того, в 1933 г. водный транспорт получил повышенные задания по подвозке строительных материалов и оборудования для находившихся в стадии постройки промышленных и сельскохозяйственных предприятий. Однако медленные темпы роста этих перевозок все еще не соответствовали росту экономики Поволжья.

Впрочем, и по пассажироперевозкам план навигации 1933 г. был недовыполнен на $22,1 \%$. Волжское пароходство перевезло 11,7 млн человек вместо 15 млн, что было почти на $16 \%$ меньше, чем в навигацию 1932 г. (13,9 млн человек) [9, л. 102-103]. Причины объяснялись простоем судов на ремонте, уменьшением и изменением направлений переброски строительных рабочих в связи с трансформацией общего плана строительства, а также возросшим на 35 \% пассажирским тарифом. Помимо этого, недостаток продуктов питания и высокие цены на них в буфетах судов сократили количество желавших воспользоваться водным транспортом отдыхающих. 
Тем не менее общая рентабельность речного флота СССР за 1931-1932 гг. была обеспечена именно за счет товаропассажирского движения и прочих операций с дополнительными сборами по грузам, с доходами от сдачи судов в аренду, сборов за простои судов и пр. Убыточным являлось буксирное движение как в целом, так и по отдельным видам перевозок (сухогрузы, нефтегрузы, плоты), а также погрузочно-выгрузочные работы. Однако прибыль от товаропассажирского движения и прочих доходов с избытком компенсировала эти потери, как компенсировала она и различные балансовые убытки (списание сомнительных и безнадежных долгов и пр.). Таким образом, в 1932 г. речной транспорт страны не имел балансового убытка, а получил прибыль в 10,4 млн рублей [10, л. 2 об.].

Рентабельность товаропассажирского движения была следствием высокого коэффициента использования пассажировместимости судов и интенсивности пассажиропотока, а также повышения в 1931 г. пассажирского тарифа. Доход по товаропассажирскому движению за 1932 г. по стране составил 134,6 млн рублей (72 \% на долю пассажиров и $28 \%$ на долю грузов) [10, л. 3].

В начале 1933 г. было проведено дальнейшее повышение пассажирских тарифов на $35 \%$. Увеличение пассажировместимости превосходило всякие допустимые нормы, поэтому нельзя было ожидать снижения себестоимости перевозок. Доход от повышения тарифа покрывал частично дополнительные расходы, связанные с пересмотром амортизационных отчислений, позволил повысить зарплату плавающему составу, повысил рентабельность.

Это с лихвой компенсировало убыточность массовых перевозок грузов буксирным движением. В свою очередь, эта убыточность была обусловлена тремя факторами:

1) включением с 1931 г. в себестоимость расходов по содержанию пути (12-14 \%), которые до этого покрывались из госбюджета;

2) ростом себестоимости перевозок за 1930-1932 гг. на 83,8 \% (особенно в 1932 г.);

3) проведенным в течение 1930-1931 гг. снижением тарифов на массовые перевозки в соответствии с правительственными директивами (на $10-50 \%$ ) [10, л. 3 об.].
В результате образовались «ножницы» между доходами и себестоимостью буксирных перевозок. Доход лишь на треть покрывал себестоимость.

По отдельным видам перевозок между УРТами разрыв был еще больше. Так, коэффициент эксплуатации по сухогрузным перевозкам Волжского УРТа за 1932 г. составлял 234, следовательно, себестоимость этих перевозок на $134 \%$ превысила доход. Такая убыточность наблюдалась по всем буксирным перевозкам всех УРТов. Доходы составляли: сдача судов в аренду, рейдовые работы, буксировка чужих судов, дополнительные сборы за взвешивание и хранение грузов и багажа, бланки накладных, штрафы по платным простоям флота по вине клиентуры. Основную массу доходов в 1931-1932 гг. составляли сборы за простои судов (на основании правительственных санкций).

В 1931 г. Волжское УРТ работало безубыточно. Его прибыль составила 3,7 млн рублей. Прибыльными оказались еще четыре из 20 УРТов: Северо-Западное (743 тыс. рублей), Днепровское (6,3 млн рублей), Западно-Сибирское (919 тыс. рублей), Иртышское (582 тыс. рублей). По доходности Волжское УРТ уступало только Днепровскому (в 1,7 раз). По стране доход от работы речного транспорта в 1931 г. составил 12,2 млн рублей, но убыток был больше - 12,4 млн рублей (пассивное сальдо баланса - 142 тыс. рублей) [10, л. 11].

В 1932 г. доход речного транспорта СССР (33,2 млн рублей) возрос в 2,7 раза по сравнению с предыдущим годом, однако увеличились убытки (22,7 млн рублей) [10, л. 10], то есть 1932 финансовый год речной флот завершил в «плюсе» (на 10,5 млн рублей). Прибыльными оказались уже девять УРТов из 20 (плюс Московский порт), в том числе: Камское (8,2 млн рублей), Северное (610 тыс. рублей), Северо-Западное (916 тыс. рублей), Днепровское (11,9 млн рублей), Днепро-Двинское (90 тыс. рублей) Западносибирское (3,3 млн рублей), Иртышское (2,1 млн рублей), Ленское (44 тыс. рублей), Среднеазиатское (5,9 млн рублей). Волжское УРТ в 1932 г., наоборот, сработало в убыток на 15,6 млн рублей [10, л. 11 об.].

Эти потери составили почти 70 \% от убытков всего речного флота СССР. Именно зани- 
жение себестоимости перевозок при больших объемах транспортировки грузов по ВУРТ вызвало такие расходы. Как отмечалось выше, волжский флот работал по самым дешевым тарифам, особенно в отличие от железнодорожного сообщения. Зато для грузоотправителей и грузополучателей снижались транспортные издержки. Это напрямую свидетельствовало об исключительном значении волжского транспорта в их обслуживании.

По Волжскому и Камскому УРТам (далее - КУРТ) почти наполовину (48,6 \%) были ниже тарифы на перевозку хлеба на расстояние в 250-750 км по сравнению с железной дорогой. Например, в среднем выходило 360 копеек за тонну зерна речным транспортом и 740 копеек - железнодорожным. Особенно выгодными перевозки волжским и камским речным транспортом оказывались на расстояние в 250 км. В 2,3 раза (на $43 \%$ ) меньше стоила перевозка лесных материалов речным флотом ВУРТ и КУРТ (в среднем 327 копеек за тонну водным транспортом и 750 копеек - железнодорожным). В 1,4 раза (на 70 \%) тарифы были ниже по перевозкам дров (в среднем 263 копейки за тонну речным флотом и 375 копеек - железнодорожным). Стоимость транспортировки соли в 3,5 раза (на 29 \%) была дешевле (в среднем 293 копейки речным транспортом за тонну и 1022 копейки - железнодорожным). Перевозка нефти наливной также была выгодна в 5,3 раза (на 18 \%). Так, в среднем выходило 165 копеек за тонну нефти речным транспортом и 881 копейка - железнодорожным. Кроме того, тарифы Волжского и Камского УРТов были ниже в 1,5 раза тарифов Днепровского УРТа и одинаковы с Западносибирским (кроме соли, перевозки которой по Западносибирскому УРТу выше более чем в два раза, чем в ВУРТе и КУРТе) [10, л. 52].

Для улучшения работы и ликвидации организационных недостатков в управлении водным транспортом НКВТ и его органы были преобразованы в соответствии с постановлениями ЦИК СССР № 89 и СНК СССР № 527 от 15 марта 1934 г. «О реорганизации органов управления водного транспорта». На основании этих решений НКВТ провел переустройство по принципу производственнотерриториального деления.
В Наркомате водного транспорта вместо ликвидируемого речного эксплуатационнотехнического управления (РЭТУ) было образовано четыре Центральных производственно-территориальных управления речного транспорта (ЦУРТ): Волжско-Камское (ВКЦУРТ), Северное, Южное, Восточное. Волжско-Камское управление речного транспорта охватывало пять пароходств: Нижневолжское, Средневолжское, Верхневолжское, Московско-Окское, Камское и Уральское. То есть в 1934 г. на Волге было организовано три новых пароходства, что должно было разграничить и облегчить контроль за перевозками на каждом отдельном отрезке реки. Волжские пароходства теперь специализировались на определенном составе перевозимых грузов. Управление работой речного транспорта стало также осуществляться на каждом отдельном участке Волги.

Таким образом, волжский транспорт за 10 лет (1923-1934 гг.) испытал на себе все те изменения, которые происходили в народном хозяйстве страны в периоды нэпа и перехода к форсированной индустриализации. С 1923 г. имели место попытки сдачи его в концессию в связи с проектом создания Волго-ДоноАзовских гидротехнических сооружений с помощью западных фирм и банков. В 1929 г. эти попытки закончились безрезультатно. Основной причиной, по всей видимости, была угроза оттока из СССР дефицитной валюты в виде прибылей концессионеров. Эта угроза перевесила обещания иностранных фирм существенно модернизировать и расширить волжский транспорт со всей его береговой инфраструктурой, а также способствовать созданию «новых грузов» в зоне операций флота.

Вплоть до своей реорганизации в 1934 г. волжский флот постоянно ощущал финансовые и технические трудности, вызванные изношенностью плавсредств, низкими тарифами на грузоперевозки и т. д. Однако те же низкие тарифы позволяли крупным новым индустриальным и сельскохозяйственным предприятиям, а также стройкам периода первых пятилеток снижать свои транспортные издержки, что должно было благоприятно сказаться на процессе индустриализации Поволжья и других регионов. Потери на грузовых перевозках компенсировались волжским водным транспортом за счет пассажир- 
ских перевозок путем увеличения высокого коэффициента использования пассажировместимости судов, интенсификации пассажиропотока и повышения пассажирского тарифа.

\section{СПИСОК ЛИТЕРАТУРЫ}

1. Булатов, В. В. Водная магистраль ВолгаДон-Азовское море: нереализованные концессии / В. В. Булатов, М. М. Загорулько. - Волгоград : Волгоградское научное издательство, 2007. - 188 с.

2. Государственный архив Волгоградской области. - Ф. 565. - Оп. 1. - Д. 2.

3. Государственный архив Российской Федерации (далее - ГАРФ). - Ф. Р-8350. - Оп. 1. - Д. 468.

4. ГАРФ. - Ф. Р-8350. - ОП. 1. - Д. 2682.

5. ГАРФ. - Ф. Р-5446. - Оп. 55. - Д. 468.

6. Политбюро ЦК РКП (б) - ВКП (б). Повестки дня заседаний. 1919-1952. Каталог. Т. 1: 1919 1929. - М. : РОССПЭН, 2000. - 832 c.

7. Рафалович, А. Л. Новая экономическая политика / А. Л. Рафалович // «Экономист». Избранное / сост. А. Л. Погорельский, А. И. Черных. - М. : Территория будущего, 2008. - С. 188-211.

8. Российский государственный архив экономики (далее - РГАЭ). - Ф. 7458. - Оп. 1. - Д. 830.

9. РГАЭ. -Ф. 7458. - ОП. 1. - Д. 831.

10. РГАЭ. - Ф. 7458. - ОП. 1. - Д. 1299.

\section{REFERENCES}

1. Bulatov V.V., Zagorulko M.M. Vodnaya magistral Volga-Don-Azovskoe more: nerealizovannye kontsessii [The Volga-Don-Azov Sea Waterway: Unrealized Concessions]. Volgograd, Volgogradskoe nauchnoe izd-vo, 2007. $188 \mathrm{p}$.

2. Gosudarstvennyy arkhiv Volgogradskoy oblasti [The State Archive of the Volgograd Region], F. 565, Op. 1, D. 2.

3. Gosudarstvennyy arkhiv Rossiyskoy Federatsii [The State Archive of the Russian Federation], F. R-8350, Op. 1, D. 468.

4. Gosudarstvennyy arkhiv Rossiyskoy Federatsii [The State Archive of the Russian Federation], F. R-8350, Op. 1, D. 2682.

5. Gosudarstvennyy arkhiv Rossiyskoy Federatsii [The State Archive of the Russian Federation], F. R-5446, Op. 55, D. 468.

6. Politbyuro TsK RKP (b) - VKP (b). Povestki dnya zasedanyy. 1919-1952. Katalog / T. 1. 19191929 [Political Bureau of the RCP (b) - All-Union CP (b) Central Committee. The Agendas. 1919-1952. Catalog. Vol. 1. 1919-1929]. Moscow, ROSSPEN Publ., 2000. 832 p.

7. Rafalovich A.L. Novaya ekonomicheskaya politika [The New Economic Policy]. PogorelskiyA.L., Chernykh A.I., eds. Ekonomist. Izbrannoe [Economist. Selected Works]. Moscow, Territoriya budushchego Publ., 2008, pp. 188-211.

8. Rossiyskiy gosudarstvennyy arkhiv ekonomiki [Russian State Archive of Economy], F. 7458, Op. 1, D. 830.

9. Rossiyskiy gosudarstvennyy arkhiv ekonomiki [Russian State Archive of Economy], F. 7458, Op. 1, D. 831.

10. Rossiyskiy gosudarstvennyy arkhiv ekonomiki [Russian State Archive of Economy], F. 7458, Op. 1, D. 1299. 